\title{
The effect of a novel botanical agent on early osteogenic response of osteoblasts
}

\author{
Young-Gon Sun ${ }^{\dagger}$, Young-Tae Kim ${ }^{\dagger}$, Xing-Hui Piao, Jong-Wook Moon, and Young-Joon Kim* \\ Department of periodontology, School of Dentistry, Chonnam National University, Gwangju 61186, Republic of Korea \\ (Received Jan 4, 2017; Revised version received [1] Mar 9, 2017 [2] Mar 21, 2017; Accepted Mar 22, 2017)
}

\begin{abstract}
A mixture of Panax notoginseng and Rehmannia glutinosa libosch (BT-301) is a synthetically developed novel botanical agent having anti-inflammatory properties. Previous studies have shown that BT-301 prevents the destruction of periodontal tissue by inhibiting the secretion of several cytokines (TNF- $\alpha$, IL-6). It was also reported that Panax notoginseng and Rehmannia glutinosa libosch have a positive influence on osteoblastic cells. However, related literatures on Panax notoginseng and Rehmannia glutinosa libosch are rare. This study aimed to evaluate the cell proliferation and osteogenic effects of BT-301 on osteoblastic cells. In dose and time kinetic studies performed, MC3T3-E1 cells cultured in $\alpha$-MEM medium were treated with varying concentrations of BT-301 (control, $0.156,0.312$, $0.625,1.25,2.5 \mathrm{mg} / \mathrm{ml}$ ), and incubated for 1,3 , and 5 days. Cell proliferation was assessed by the MTT assay. Alkaline phosphatase (ALP) activity of MC3T3-E1 cells was measured on day 7. Results show that MC3T3-E1 cells exposed to BT-301 at $0.156 \mathrm{mg} / \mathrm{ml} \mathrm{and}$ $0.312 \mathrm{mg} / \mathrm{ml}$ concentrations, showed greater cell proliferation on day $3(\mathrm{p}<0.05)$. We conclude that correct exposure to the optimal concentration of BT-301 has a positive effect on bone healing.
\end{abstract}

KEY WORDS: Alkaline phosphatase (ALP), Cell proliferation, Panax notoginseng, Rehmannia glutinosa libosch

\section{Introduction}

Periodontitis is characterized by chronic inflammation and destruction of tooth supporting tissues (periodontal ligament, cementum, and bone) [1]. Loss of supporting tissue causes the teeth to become mobile and eventually fall out. The development of host-modulatory agents with low risk of adverse effects has been needed to treat periodontitis.

Successful periodontal therapy is dependent on antiinfective procedures aimed at eliminating pathogenic organisms found in dental plaque attached to the tooth surface $[2,3]$. A small, although relevant proportion of sites and patients, do not respond adequately to mechanical debridements [4]. In this respect, the use of host-modulatory

\footnotetext{
These authors contributed equally to this work.

*Corresponding author: Young-Joon Kim

Department of periodontology, School of Dentistry, Chonnam National University, 33 Yongbong-ro, Buk-gu, Gwangju 61186, Republic of Korea Tel.: +82-62-530-5648, Fax: +82-62-530-5649

E-mail: youngjun@chonnam.ac.kr
}

agents have been emerging in periodontal treatment strategies rather than only mechanical and surgical treatments, and numerous agents such as anti-inflammatory and antioxidant agents were investigated [5].

Non-steroidal anti-inflammatory drugs (NSAIDs) and antimicrobial agents are used for the cessation of periodontitis progression. Although they may reduce the proportion of gingival bleeding sites and pocket depth and improve clinical attachment level and radiographic alveolar bone level, there are some reports showing adverse effects of these agents that frequently related to the gastrointestinal tract, superinfection and rarely to the fetal toxicity (metronidazole and erythromycin) $[6,7]$.

A novel botanic agent, named BT-301, was synthesized by mixing extracts from two substances, Panax notoginseng and Rehmannia glutinosa libosch, to prevent the progression of periodontitis with lower risk of adverse effects.

Panax notoginseng, a medicinal Chinese herb, has been used to treat bone fracture for over a thousand years and its major component, ginsenoside Rg1, was found to stimulate the proliferation of bone marrow stromal cells and increase the number of osteoblasts in vitro $[8,9]$. Panax 
notoginseng also inhibits LPS-induced activation of RAW264.7 macrophages and possesses anti-inflammatory and immunosuppressive properties in vitro $[10,11]$. Moreover in previous study by Li et al. [12] $0.1 \mathrm{mg} / \mathrm{ml}$ of Panax notoginseng saponinscan promote osteogenesis of bone marrow stromal cells by targeting osteogenesis-associated genes.

Rehmannia glutinosa libosch extracts is isolated from the Rehmanniae radix [13]. The major constituents of Rehmannia glutinosa libosch are h-sitosterol and mannitol. The other constituents include a small amount of stigmasterol and a trace amount of campesterol, catalpol, rehmannin and vitamin A $[14,15]$. In previous study by Oh et al. [16] $0.6 \mathrm{~g} / \mathrm{ml}$ of Rehmannia glutinosa libosch stimulates proliferation and activities of osteoblasts, while inhibiting the generation and resorptive activities of osteoclasts. It may inhibit TNF- $\alpha$ secretion by inhibiting IL-1 secretion and have an anti-inflammatory activity in the central nervous system curing some pathological disease states $[17,18]$.

Combination of Panax notoginseng and Rehmannia glutinosa libosch was denominated as BT-301 by Lee et al [19]. they showed that BT-301 prevents destruction of periodontal tissue by inhibiting the secretion of several cytokines (TNF- $\alpha$, IL-6) engaged in destruction of periodontal tissue. Moreover, they studied the effect of BT301 on LPS-induced alveolar bone resorption in rats and showed reduced alveolar bone resorption [19]. However, it was reported that Panax notoginseng and Rehmannia glutinosa libosch have positive effects on osteoblastic cells as well $[12,16]$. Therefore, the aim of this study was to evaluate the effects of BT-301 on osteoblastic cells.

\section{Materials and Methods}

\section{Preparation of BT-301}

BT-301, the mixture of extracts from two natural substances, Panax notoginseng and Rehmannia glutinosa libosch was prepared in powder form by Botanical Agent Development Team from OSCOTEC Incorporation (OCT Inc, Cheonan, Korea) and the suitability of test materials was confirmed by a quality control process with reference material. This agent is composed of extracts from two natural substances, Panax notoginseng and Rehmannia radix preprata (9:1, weight). The two substances were extracted with 13 times purified water at $100^{\circ} \mathrm{C}$ temperature. After filtration of the extract, it was concentrated and dried. The dry extract was solved with serum free media, and then the solution was filtered through $0.2 \mu \mathrm{m}$ pore size filter. BT-301, with initiative concentration of $2.5 \mathrm{mg} / \mathrm{ml}$ was produced and diluted into $0.156 \mathrm{mg} / \mathrm{ml}, 0.312 \mathrm{mg} / \mathrm{ml}$, $0.625 \mathrm{mg} / \mathrm{ml}, 1.25 \mathrm{mg} / \mathrm{ml}$ and $2.5 \mathrm{mg} / \mathrm{ml}$ to be used in the experiment.

\section{Culture of osteoblastic cells}

The osteoblastic cell line MC3T3-E1 (ATCC, Rockville, $\mathrm{MD}$, USA) has been established from a C57BL/6 mouse calvaria and selected on the basis of high ALP activity in the resting state. Cells have the capacity to differentiate into osteoblasts and osteocytes and have been demonstrated to form calcified bone tissue in vitro. MC3T3-E1 cells were cultured in $\alpha$-MEM media (Life Technologies, USA) supplemented with $10 \%$ heat-inactivated fetal bovine serum (FBS), $100 \mathrm{mg} / \mathrm{ml}$ penicillin and $100 \mathrm{mg} / \mathrm{ml} \mathrm{strep-}$ tomycin at $37^{\circ} \mathrm{C}$ in humidified atmosphere of $5 \% \mathrm{CO}_{2}$ and $95 \%$ air.

\section{Cell proliferation test (MTT assay)}

MC3T3-E1 cells were seeded into 96-well tissue culture plate $1 \times 10^{4}$ cells in $\alpha$-MEM supplemented with $10 \%$ heatinactivated fetal bovine serum (FBS), $100 \mathrm{mg} / \mathrm{ml}$ penicillin and $100 \mathrm{mg} / \mathrm{ml}$ streptomycin at $37^{\circ} \mathrm{C}$ in humidified atmosphere of $5 \% \mathrm{CO}_{2}$ and $95 \%$ air per well for 1 day. The cells were treated with varying concentrations of BT$301(0.156,0.312,0.625,1.25,2.5 \mathrm{mg} / \mathrm{ml})$ in $\alpha$-MEM. BT-301 untreated cells were classed as control group. And the cells were incubated for 1day, 3days and 5days. Afterward, the cells were estimated by MTT assay (CellTiter 96 R AQueous Solution, Promega, USA) after washing detached cells. The absorbance was read at 490nm with ELISA reader (VERSAmaxTM, Dynamic Device, USA). MTT assay was duplicated and the mean values were calculated.

\section{Alkaline phosphatase (ALP) activity}

ALP activity in treated MC3T3-E1 cells were measured spectro-photometrically at day 7. Briefly, MC3T3-E1 cells were seeded in a 12-well plate at a density of $1 \times 10^{4}$ cells/ $\mathrm{ml}$ in $\alpha$-MEM media (Life Technologies, USA) supplemented with $10 \%$ heat-inactivated fetal bovine serum (FBS), $100 \mathrm{mg} / \mathrm{ml}$ penicillin and $100 \mathrm{mg} / \mathrm{ml}$ streptomycin at $37^{\circ} \mathrm{C}$ in humidified atmosphere of $5 \% \mathrm{CO}_{2}$ and $95 \%$ air. The cells were treated with varying concentrations of BT$301(0.156,0.312,0.625 \mathrm{mg} / \mathrm{ml})$. BT-301 untreated cells were classed as control group. At day 7 , the cells were 
lysed in Triton $0.1 \%$ (Invit-rogen Corp., USA) in phosphate buffered saline (PBS, Invitrogen Corp., USA). One hundred microliter of the cell lysates was mixed with $200 \mu \mathrm{l}$ of $10 \mathrm{mM}$ p-nitrophenol phosphate and 100: 1 of 1.5M 2-amino-2-methyl-1-propanol buffer, and incubated for $60 \mathrm{~min}$ in an oven at $60 \mathrm{w}^{\circ} \mathrm{C}$. The ALP activity was measured by absorbance at $405 \mathrm{~nm}$ with ELISA reader (VERSAmaxTM, Dynamic Device, USA).

\section{Statistical analysis}

SPSS software package (Ver.20.0) was used to assess the result of roughness test, MTT assay and ALP activity between groups with one-way ANOVA and Tukey's post hoc test was performed to assess the significance of the difference between groups. Data was presented as the mean values with standard deviations. A p-value $<0.05$ was considered statistically significant.

\section{Results}

\section{Cell proliferation test (MTT assay)}

Figure 1 shows optical density measurements at each concentration after 1 day, 3 days and 5 days, and it can be compared with that of control group.
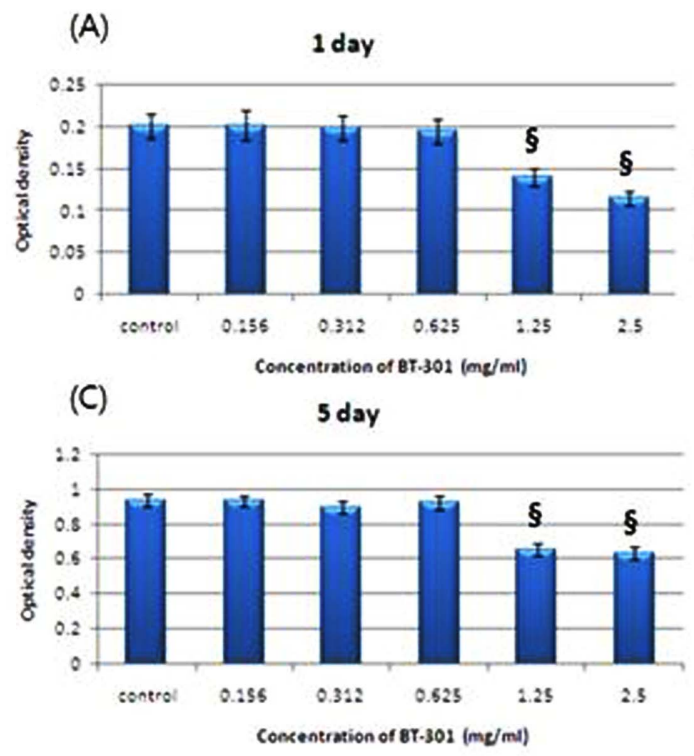

Optical density increased in all groups with the lapse of time. At first day, optical density of the cells treated with $0.156 \mathrm{mg} / \mathrm{ml}, 0.312 \mathrm{mg} / \mathrm{ml}$ and $0.625 \mathrm{mg} / \mathrm{ml}$ concentration of BT-301 was similar to that of the control group, but optical density of the cells treated with $1.25 \mathrm{mg} / \mathrm{ml}$ and 2.5 $\mathrm{mg} / \mathrm{ml}$ concentration of BT-301 was significantly lower than that of the control group. At third day, optical density of the cells treated with $0.156 \mathrm{mg} / \mathrm{ml}, 0.312 \mathrm{mg} / \mathrm{ml}$ and $0.625 \mathrm{mg} / \mathrm{ml}$ concentration of BT-301 was significantly higher than that of the control group. At fifth day, likewise 1st day, optical density of the cells treated with $0.156 \mathrm{mg} /$ $\mathrm{ml}, 0.312 \mathrm{mg} / \mathrm{ml}$ and $0.625 \mathrm{mg} / \mathrm{ml}$ concentration of BT301 was similar to that of the control group.

Optical density increased significantly in $0.156 \mathrm{mg} / \mathrm{ml}$, $0.312 \mathrm{mg} / \mathrm{ml}$ and $0.625 \mathrm{mg} / \mathrm{ml}$ concentrations of BT-301 treated cells compared to the control group in the third day $(\mathrm{p}<0.05)$. Post hoc analysis showed significantly high cell activity in order of $0.312 \mathrm{mg} / \mathrm{ml}, 0.156 \mathrm{mg} / \mathrm{ml}$ and 0.625 $\mathrm{mg} / \mathrm{ml}$ concentration of BT- 301 treated cells.

\section{Alkaline phosphatase (ALP) activity}

The ALP activity of the cell treated with BT-301 (0.156, $0.312 \mathrm{mg} / \mathrm{ml}$ ) was significantly higher than the control group. Although treated cell with $0.625 \mathrm{mg} / \mathrm{ml}$ of BT-301 showed slightly higher ALP activity, as compared to the
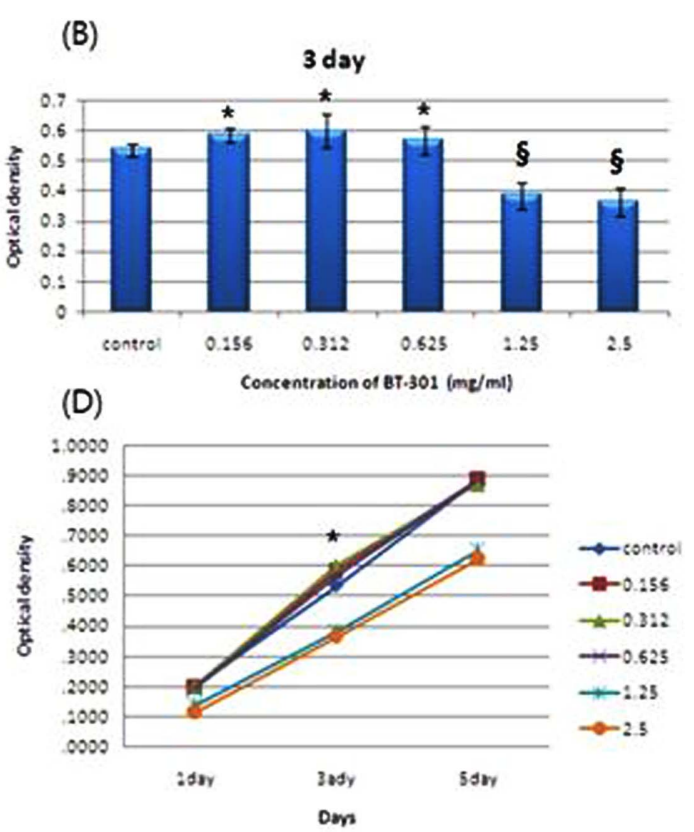

Fig. 1. MTT assay of MC3T3-E1 cell treated with various concentration of BT-301 at day 1, 3 and 5. Optical density measurements at each concentration after 1 day (A), 3 days (B) and 5 days (C) and it can be compared with that of control group (D). At third day, optical density of treated with $0.156,0.312$ and $0.625 \mathrm{mg} / \mathrm{ml}$ concentration of BT-301 was significantly higher than that of the control groups ( $<<0.05)$. At day 1 and 5, there was no significant difference of optical density between control and test group. 


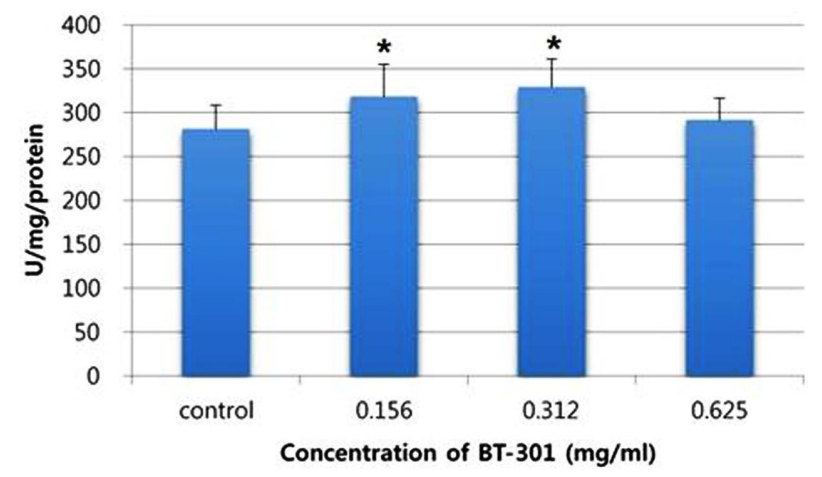

Fig. 2. The ALP activity of the MC3T3-E1 cell treated with BT$301(0,0.156,0.312,0.625 \mathrm{mg} / \mathrm{ml})$ Treated with 0.156 and 0.312 $\mathrm{mg} / \mathrm{ml}$ concentration of BT-301 was significantly higher than that of the control group ( $>0.05$ ). Treated with $0.625 \mathrm{mg} / \mathrm{ml}$ concentration of BT-301 showed higher ALP activity than control group, however there was no significant difference $(p>0.05)$.

control group, however there was no statistically significant difference ( $>0.05$ ) (Fig. 2).

\section{Discussion}

Various agents were investigated for periodontal treatment, but there are some adverse effects of these agents $[6,7]$. Therefore, we developed a novel botanical agent, named BT-301, which is composed of extracts from Panax notoginseng and Rehmannia radix preprata. This study aimed to evaluate the cell proliferation property and the osteogenic effects of BT-301 on osteoblastic cells via MTT assay and ALP activity test.

BT-301 contains $0.8 \%$ ginsenoside $\mathrm{Rb} 1\left(\mathrm{C}_{54} \mathrm{H}_{92} \mathrm{O}_{23}\right)$ and $0.0045 \% 5$-hydroxymethyl-2-furaldehyde $\left(\mathrm{C}_{6} \mathrm{H}_{6} \mathrm{O}_{3}\right)$. Ginsenoside $\mathrm{Rb} 1$, a known phytoestrogen, is the main active component of ginseng. It has been reported that Ginsenoside $\mathrm{Rb} 1$ inhibit osteoclastogenesis by modulating NF- $\mathrm{kB}$ and MAPKs pathways [20]. In that study, to determine whether Ginsenoside Rb1 has toxic effects on Raw264.7 cells, they evaluated the viability of Raw 264.7 cells by MTT assay. At the concentrations used in that study $(0$, $0.1 \mu \mathrm{M}, 1 \mu \mathrm{M}, 10 \mu \mathrm{M})$, Ginsenoside Rb1 did not show any cytotoxicity in Raw264.7 cells. The results indicate Ginsenoside Rb1 contributes to the anti-osteoporosis activity of Ginsenosides. 5-hydroxymethyl-2-furaldehyde, an organic compound derived from dehydration of certain sugars, is known to have anti-inflammatory effect through downregulation of NF-kB level [21].

In previous study by Lee et al. [19] BT-301 showed cytotoxicity on human gingival fibroblastic and human periodontal ligament cells at concentration exceeding 1.25 $\mathrm{mg} / \mathrm{ml}$ at first day. In contrast, BT-301 at concentration under $1.25 \mathrm{mg} / \mathrm{ml}$ showed a tendency to increase in cell viability [19]. In this study, the treated cells with $1.25 \mathrm{mg} /$ $\mathrm{ml}$ and $2.5 \mathrm{mg} / \mathrm{ml}$ concentration of BT-301 presented low cell activity which is statistically significant. This study showed that the cell proliferation increased from first day to fifth day at each concentration, but cell proliferation was significantly low at 1.25 and $2.5 \mathrm{mg} / \mathrm{ml}$ concentration, that is, cytotoxicity was present at high concentration such as 1.25 and $2.5 \mathrm{mg} / \mathrm{ml}$. This result is consistent with previous study that showed in which concentration the cytotoxicity begins at $1.25 \mathrm{mg} / \mathrm{ml}$ concentration of BT-301. Therefore BT-301 at those concentrations were not used in ALP activity test to evaluate the osteogenic effect of BT301 on osteoblastic cells. Kim et al. [22] reported the cytotoxic of total saponin, one of the major components of Pannax ginseng root, on hPDL cells at high concentration $(1 \mathrm{mg} / \mathrm{ml})$. They also showed that the low concentration (under $0.1 \mathrm{mg} / \mathrm{ml}$ ) of saponin enhanced cell proliferation rather than showed a cytotoxic effect.

In previous study, Lee et al. [19] have proposed clinically usable concentration rate by discovering BT-301's cytotoxic concentration level, but they couldn't find out cell proliferation ability of BT-301 treated with the concentration of just before cytotoxic level. Accordingly, in this study the cell proliferation ability of BT-301 on the osteoblastic cells was determined with the MTT assay. As a result, significant increase in cell viability was observed in $0.156 \mathrm{mg} / \mathrm{ml}, 0.312 \mathrm{mg} / \mathrm{ml}$ and $0.156 \mathrm{mg} / \mathrm{ml}$ concentration compared to the control group after 3 days. This result is a significant discovery that BT-301 can stimulate cell proliferation ability on the osteoblastic cells.

Significant differences between each concentration level in third days with increase of cell viability was obtained and high cell viability was observed in order of $0.312 \mathrm{mg} /$ $\mathrm{ml}, 0.156 \mathrm{mg} / \mathrm{ml}$ and $0.625 \mathrm{mg} / \mathrm{ml}$ after post hoc analysis. The result indicates that $0.312 \mathrm{mg} / \mathrm{ml}$ is the concentration of BT-301 which shows the most evident cell proliferation rate. In this respect, it appears to be meaningful that the most effective concentration of cell proliferation ability is revealed.

The metalloenzyme known as alkaline phosphatase exists as several tissue-specific isozymes encoded by separate genes. Humans have four ALP genes corresponding to intestinal, placental, placental-like and liver/bone/kidney (tissue non- 
specific; TNAP) gene products [23]. ALP was one of the first key marker in the process of osteogenesis to be recognized. The high ALP level is sure to provide new and important information into the fundamental mechanisms of hard tissue formation, provide therapeutic opportunities for treatment of bone diseases [24].

In this study, ALP activity test was performed in the concentration rate of $0.156 \mathrm{mg} / \mathrm{ml}, 0.312 \mathrm{mg} / \mathrm{ml}$ and 0.625 $\mathrm{mg} / \mathrm{ml}$ group just before cytotoxic level. As a result, the ALP activity has increased significantly in the $0.156 \mathrm{mg} /$ $\mathrm{ml}$ group and $0.312 \mathrm{mg} / \mathrm{ml}$ group compared to the control group. In previous studies, Panax notoginseng and Rehmannia glutinosa libosch, raw material of BT-301, showed a statistically significant increase in ALP activity $(0.1 \mathrm{mg} /$ $\mathrm{ml}$ of Panax notoginseng saponin or $0.6 \mathrm{~g} / \mathrm{ml}$ of Rehmannia glutinosa libosch $[12,16]$. Alike previous study about raw material of BT-301, this study $(0.156 \mathrm{mg} / \mathrm{ml}$ group and $0.312 \mathrm{mg} / \mathrm{ml}$ group) showed significant difference of ALP activity compared to the control group. Therefore, ALP activity tests conclude that proper concentration of BT-301 had osteogenic effect. BT-301 seems to contain active components that have a potential to enhance the bone metabolism in osteogenesis. To confirm the exact osteogenic effect of BT 301 on osteoblastic cells, further in vitro and in vivo clinical studies are necessary.

This research was carried out to evaluate the effect of BT-301 on osteoblastic cells. It showed that BT-301 had positive effects on osteogenic proliferation at $0.156 \mathrm{mg} /$ $\mathrm{ml}, 0.312 \mathrm{mg} / \mathrm{ml}$ and $0.625 \mathrm{mg} / \mathrm{ml}$ concentration of BT301.

\section{Conclusions}

In this study, the cell proliferation effects and the osteogenic effects of BT-301 on MC3T3-E1 cells were evaluated by Cell proliferation test (MTT assay) and ALP activity test.

1. In cell proliferation test (MTT assay), $0.156 \mathrm{mg} / \mathrm{ml}$, $0.312 \mathrm{mg} / \mathrm{ml}$ and $0.625 \mathrm{mg} / \mathrm{ml}$ of BT-301 showed higher cell proliferation property compared to the control group at 3 days $(\mathrm{p}<0.05)$.

2. In ALP activity test, Treated with 0.156 and 0.312 $\mathrm{mg} / \mathrm{ml}$ concentration of BT-301 was significantly higher than that of the control group $(\mathrm{p}<0.05)$.

Proper concentrations of BT-301 seems to have positive effects on osteoblastic cell to help bone healing. Further research is necessary to determine the exact osteogenic effects of BT-301 and for clinical application of these mixtures.

\section{Conflict of Interest}

The authors declare that they have no competing interests.

\section{ORCID}

$\begin{array}{ll}\text { Young-Gon Sun } & 0000-0002-9169-7522 \\ \text { Young-Tae Kim } & 0000-0003-4305-1839 \\ \text { Xing-Hui Piao } & 0000-0003-4497-4977 \\ \text { Jong-Wook Moon } & 0000-0002-6688-0210 \\ \text { Young-Joon Kim } & 0000-0003-1397-8166\end{array}$

\section{References}

1. Burt B. Research, Science and Therapy Committee of the American Academy of Periodontology. Position paper: epidemiology of periodontal diseases. J Periodontol 2005; 76:1406-1419. doi: 10.1902/jop.2005.76.8.1406.

2. Bollen CM, Mongardini C, Papaioannou W, Steenberghe $\mathrm{D}$, Quirynen M. The effect of a onestage full-mouth disinfection on different intra-oral niches Clinical and microbiological observations. J Clin Periodontol 1998;25:5666. doi: 10.1111/j.1600-051X.1998.tb02364.x.

3. Slots J. Subgingival microflora and periodontal disease. J Clin Periodontol 1979;6:351-382. doi: 10.1111/j.1600051X.1979.tb01935.x.

4. Walker CB, Gordon JM, Magnusson I, Clark WB. A role for antibiotics in the treatment of refractory periodontitis. J Periodontol 1993;64:772-781. doi: 10.1902/jop.1993.64. 8s.772.

5. Bhatavadekar NB, Williams RC. New directions in host modulation for the management of periodontal disease. $\mathrm{J}$ Clin Periodontol 2009;36:124-126. doi: 10.1111/j.1600051X.2008.01354.x.

6. Slots J, Ting M. Systemic antibiotics in the treatment of periodontal disease. Periodontol 2000 2002;28:106-176. doi: 10.1034/j.1600-0757.2002.280106.x.

7. Herrera D, Sanz M, Jepsen S, Needleman I, Roldan S. A systematic review on the effect of systemic antimicrobials as an adjunct to scaling and root planing in periodontitis patients. J Clin Periodontol 2002;29:136-159. doi: 10.1034/j.1600-051X.29.s3.8.x.

8. Gong YS, Chen J, Zhang QZ, Zhang JT. Effect of 17beta- 
oestradiol and ginsenoside on osteoporosis in ovariectomised rats. J Asian Nat Prod Res 2006;8:649-656. doi: $10.1080 / 10286020500246063$.

9. Lu XZ, Wang JH, Wu X, Zhou L, Wang L, Zhang XW, Cao KJ, Huang J. Ginsenoside Rg1 promotes bone marrow stromal cells proliferation via the activation of the estrogen receptormediated signaling pathway. Acta Pharmacol Sin 2008;29:1209-1214. doi: 10.1111/j.1745-7254. 2008.00874.x.

10. Rhule A, Navarro S, Smith JR, Shepherd DM. Panax notoginseng attenuates LPS-induced pro-inflammatory mediators in RAW264.7 cells. J Ethnopharmacol 2006;106: 121-128. doi: 10.1016/j.jep.2005.12.012.

11. Jin UH, Park SG, Suh SJ, Kim JK, Kim DS, Moon SK, $\mathrm{Kim} \mathrm{CH}$. Inhibitory effect of Panax notoginseng on nitric oxide synthase, cyclo-oxygenase-2 and neutrophil functions. Phytother Res 2007;21:142-148. doi: 10.1002/ptr.2018.

12. Li XD, Chang B, Chen B, Liu ZY, Liu DX, Wang JS, Du SX. Panax notoginseng saponins potentiate osteogenesis of bone marrow stromal cells by modulating gap junction intercellular communication activities. Cell Physiol Biochem 2010;26:1081-1092. doi: 10.1159/000323986.

13. Kim HM, Lee EH, Lee SJ, Shin TY, Kim YJ, Kim JB. Effect of Rehmannia glutinosa on immediate type allergic reaction. Int J Immunopharmacol 1998;20:231-240. doi: 10.1016/S0192-0561(98)00037-X.

14. Chang HM, But PPH. Pharmacology and applications of Chinese amteria medica. Vol 1, Translated by Yao SC, Wang LL,Shem CS, English edit. 461; 1986.

15. Ni M, Bian B, Wang H. Constituents of the dry roots of Rehmannia glutinosa Libosch. Zhongguo Zhongyao Zazhi 1992;17:297-298.

16. Oh KO, Kim SW, Kim JY, Ko SY, Kim HM, Baek JH, Kim JK. Effect of Rehmannia glutinosa Libosch extracts on bone metabolism. Clin Chim Acta 2003;334:185-195. doi: 10.1016/S0009-8981(03)00238-9.

17. Kim HM, An CS, Jung KY, Choo YK, Park JK, Nam SY. Rehmannia glutinosa inhibits tumour necrosis factoralpha and interleukin-1 secretion from mouse astrocytes. Pharmacol Res 1999;40:171-176. doi: 10.1006/phrs.1999. 0504.

18. Zhang RX, Li MX, Jia ZP. Rehmannia glutinosa: review of botany, chemistry and pharmacology. J Ehnopharmacol 2008;117:199-214. doi: 10.1016/j.jep.2008.02.018.

19. Lee BA, Lee HS, Jung YS, Kim SW, Lee YW, Chang SH, Chung HJ, Kim OS, Kim YJ. The effects of a novel botanical agent on LPS-induced alveolar bone loss in rats. J Periodontol 2013;84:1221-1229. doi: 10.1902/jop. 2012.120460.

20. Cheng B, Li J, Du J, Lv X, Weng L, Ling C. Ginsenoside $\mathrm{Rb} 1$ inhibits osteoclastogenesis by modulating NF- $\mathrm{KB}$ and MAPKs pathways. Food Chem Toxicol 2012;50: 1610-1615. doi: 10.1016/j.fct.2012.02.019.

21. Kim HK, Choi YW, Lee EN, Park JK, Kim SG, Park DJ, Yoon S. 5-Hydroxymethylfurfural from black garlic extract prevents TNF $\alpha$-induced monocytic cell adhesion to HUVECs by suppression of vascular cell adhesion molecule-1 expression, reactive oxygen species generation and NF- $\mathrm{BB}$ activation. Phytother Res 2011;25:965-974. doi: 10.1002/ptr.3351.

22. Kim IG, Kim JG, Lee JH. The effect of Korean red ginseng saponin on the growth and differentiation of human periodontal ligament cell in culture. J Periodontal Implant Sci. 1995;25:45-55.

23. Moss DW. Perspectives in alkaline phosphatase research. Clin Chem 1992;38:2486-2492.

24. Golub EE, Boesze-Battaglia K. The role of alkaline phosphatase in mineralization. Curr Opin Orthop 2007;18: 444-448. 